\title{
IN-VITRO ANTIOXIDANT ACTIVITY OF PLANT ELAEOCARPUS TUBERCULATUS ROXB.
}

\author{
Vikas R. Mathad ${ }^{{ }^{1}}$, Jayadevaiah K.V. ${ }^{1}$, Vinay R. ${ }^{1}$, Basavaraja H. S. ${ }^{1}$, Bharathi D. R. ${ }^{2}$, Rajashekhar K. V. ${ }^{3}$
}

SJM College of Pharmacy, SJMIT Campus, Chitradurga, Karnataka, India.

${ }^{1}$ PG Department of Pharmaceutical Chemistry,

${ }^{2} \mathrm{PG}$ Department of Pharmacology,

${ }^{3}$ Sri Raghavendra Ayurvedic Medical College, Malladihalli, Karnataka, India.

Article Info: Received 30 April 2019; Accepted 02 June. 2019

DOI: https://doi.org/10.32553/jbpr.v8i3.608

Address for Correspondence: Vikas R. Mathad, PG Department of Pharmaceutical Chemistry, SJM College of Pharmacy, SJMIT Campus, NH4, Chitradurga, Karnataka, India.

Conflict of interest statement: No conflict of interest

\section{ABSTRACT:}

A majority of the population in the developing world is struggling to raise living standards and improve health-care delivery due to increasing poverty and population. According to an estimate, $70-80 \%$ of the developing world is dependent on conventional plant-obtained remedies, as pharmaceuticals are high priced, so the present study was aimed at evaluating the crude ethanolic extract of stem bark of plant Elaeocarpus tuberculatus Roxb. belonging to the family Elaeocarpaceae with in-vitro antioxidant activity by following various methods namely total reducing power and free radical scavenging activity was evaluated using 1,1diphenyl-2-picryl hydrazyl (DPPH) free radical. The crude ethanolic extract possesses significant concentration dependent inhibition of DPPH activity and concentration dependent increase in reducing power property against the standard ascorbic acid. Our findings provide evidence that the crude ethanolic extract of stem bark of Elaeocarpus tuberculatus Roxb. is a potential source of natural antioxidant.

Keywords: Elaeocarpus tuberculatus Roxb., 1,1-diphenyl-2-picryl hydrazyl (DPPH), Total reducing power, ascorbic acid.

\section{INTRODUCTION}

Free radicals can be defined as molecules or molecular fragments containing one or more unpaired electrons. The presence of unpaired electrons usually confers a considerable degree of reactivity upon a free radical. Those radicals derived from oxygen represent the most important class of such species generated in living systems.

Oxygen-free radicals, more generally known as reactive oxygen species (ROS) along with reactive nitrogen species (RNS) are well recognised for playing a dual role as both deleterious and beneficial species. The "two-faced" character of ROS is substantiated by growing body of evidence that ROS within cells act as secondary messengers in intracellular signalling cascades, which induce and maintain the oncogenic phenotype of cancer cells, however, ROS can also induce cellular senescence and apoptosis and can therefore function as anti-tumorigenic species. The cumulative production of ROS/RNS through either endogenous or exogenous insults is termed oxidative stress and is common for many types of cancer cell that are linked with altered redox regulation of cellular signalling pathways. Oxidative stress induces a cellular redox imbalance which has been found to be present in various cancer cells compared with normal cells; the redox imbalance thus may be related to oncogenic stimulation. DNA mutation is a critical step in carcinogenesis and elevated levels of oxidative DNA lesions (8-OH-G) have been noted in various tumours, strongly implicating such damage in the etiology of cancer. 
Vikas R. Mathad et al., Journal of Biomedical and Pharmaceutical Research

It appears that the DNA damage is predominantly linked with the initiation process.

\section{Free radical formation}

The free radicals are formed through;

- Products of metal catalysed reaction.

- Produced by neutrophils and macrophages during inflammation.

- By products of mitochondria- catalysed electron transfer reaction and other mechanism.

- The irradiation by UV light, by X-rays and gamma rays.

- $\quad$ Present as pollutants in atmosphere ${ }^{1}$.

There are a number of potential sites for freeradical species generation within muscle. The mitochondria normally will utilize molecular oxygen to form ATP for energy. It has been reported that approximately 2 to $5 \%$ of the total oxygen flux through the mitochondria can form superoxide radicals. The site for this apparent loss of oxygen has been proposed to be at the coenzyme $Q$ level of the electron transport. If there is a greater oxygen demand on the muscle, it would be logical to predict that more superoxide radicals would be generated. However, it should be noted that mitochondria are well protected by antioxidant enzymes to help degenerate these superoxide radicals.

Another possible mechanism of free-radical production occurs when xanthine oxidase is formed from xanthine dehydrogenase in the presence of hypoxanthine to form uric acid and a superoxide radical. In order for this process to proceed, calcium-activated proteases need to be activated. It has been indicated that calcium homeostasis can be compromised during excessive contraction of the muscle. However, this is a potential mechanism needs to be substantiated in exercise-induced muscle damage. It has been sugested that prostonoids are released and appear in skeletal muscle when subjected to excessive contractile activity. Some of the intermediates of prostanoid breakdown are free radicals. It is unclear whether prostonoids are elevated during and are present within the damaged muscle, but this been proposed ${ }^{2}$.

\section{Properties of free radicals}

Free radicals with an unpaired electron have the following properties:

- Highly reactive, extremely short life span measured in micrograms.

- Self-perpetuating and diverse chemical reactivity.

- $\quad$ Low chemical specificity.

- $\quad$ Can be generated both in-vivo and in-vitro ${ }^{3}$.

Some of the medicinal plants are screened for invitro antioxidant activity by following DPPH method where the green tea (Camellia sinensis Linn.) shows the strongest activity and black tea (Camellia sinensis Linn.), Eugenia caryophyllus, Piper cubeba Linn, Zingiber officinale Roscoe, Piper nigrum Linn shows the significant free radical scavenging activity ${ }^{4}$.

Elaeocarpus tuberculatus Roxb., belongs to the family Elaeocarpaceae. It is distributed in Indomalaysia; in the Western Ghats- South and Central Sahyadris. It's a common emergent and canopy trees in evergreen to semi-evergreen forests usually along stream banks up to $1400 \mathrm{~m}$.

The decoction of the bark is given in haematemesis and biliousness and the nuts are used in rheumatism, typhoid fever and epilepsy.

Based on ancient practices and traditional uses of this plant, an effort has been made to establish the anti-oxidant activity of ethanolic extract of stem bark of plant Elaeocarpus tuberculatus Roxb. ${ }^{5-7}$.

\section{MATERIALS AND METHODS}

\section{Collection and authentication of the plant:}

Bark was collected from the surrounding of Virajpet, Kodagu (Dist.), Karnataka, India on June24, 2018. The plant was authenticated by Prof. Dr. V. T. Hiremath. M.Sc., Ph.D., Department of Botany, SJM College of Arts, Science and Commerce, Chitradurga, Karnataka, India.

\section{Preparation of the ethanolic extract:}

The dried stem barks were powdered $(5 \mathrm{~kg})$ and subjected to soxhlet extraction with ethanol (95\%) to get ethanolic extract. The process was repeated for six times. The solvent from the total extract was distilled off and the concentrate was evaporated 
Vikas R. Mathad et al., Journal of Biomedical and Pharmaceutical Research

on a water bath to a syrupy consistency and then evaporated to dryness (120 g).

\section{Preliminary phytochemical screening (Qualitative analysis) $^{8}$ :}

The preliminary phytochemical studies were performed on the ethanolic extract of the stem bark of Elaeocarpus tuberculatus Roxb. and the results are shown in Table 01.

\section{Alkaloids}

\section{(a) Dragendorff's test}

To $2 \mathrm{mg}$ of the ethanolic extract $5 \mathrm{ml}$ of distilled water was added, $2 \mathrm{M}$ Hydrochloric acid was added until an acid reaction occurs. To this $1 \mathrm{ml}$ of Dragendorff's reagent was added. Formation of orange or orange red precipitate indicated the presence of alkaloids.

\section{(b) Hager's test}

To $2 \mathrm{mg}$ of the ethanolic extract taken in a test tube, a few drops of Hager's reagent were added. Formation of yellow precipitate confirmed the presence of alkaloids.

\section{(c) Wagner's test}

$2 \mathrm{mg}$ of ethanolic extract was acidified with $1.5 \% \mathrm{v} / \mathrm{v}$ of hydrochloric acid and a few drops of Wagner's reagent were added. A yellow or brown precipitate indicated the presence of alkaloids.

\section{(d) Mayer's test}

To a few drops of Mayer's reagent, $2 \mathrm{mg}$ of ethanolic extract was added. Formation of white or pale yellow precipitate indicated the presence of alkaloids.

\section{Carbohydrates}

\section{(a) Anthrone test}

To $2 \mathrm{ml}$ of Anthrone reagent solution, $0.5 \mathrm{ml}$ of alcoholic extract was added. Formation of green or blue colour indicated the presence of carbohydrates.

\section{(b) Benedict's test}

To $0.5 \mathrm{ml}$ of aqueous extract, $5 \mathrm{ml}$ of Benedict's solution was added and boiled for 5 minutes. Formation of brick red coloured precipitate indicated the presence of carbohydrates.

\section{(c) Fehling's test}

To $2 \mathrm{ml}$ of aqueous extract, $1 \mathrm{ml}$ mixture of equal parts of Fehling's solution A and B were added and boiled for few minutes. Formation of red or brick red coloured precipitate indicated the presence of reducing sugars.

\section{(d) Molisch's test}

In a test tube containing $2 \mathrm{ml}$ of alcoholic extract, 2 drops of freshly prepared $20 \%$ alcoholic solution of $\alpha$-naphthol was added. $2 \mathrm{ml}$ of Conc. Sulphuric acid was added so as to form a layer below the mixture. Red-violet ring appeared, indicating the presence of carbohydrates, which disappeared on the addition of excess of alkali.

\section{Flavonoids}

\section{(a) Shinoda's test}

In a test containing $0.5 \mathrm{ml}$ of the ethanolic extract, 10 drops of dilute hydrochloric acid followed by a small piece of magnesium were added. Formation of pink, reddish or brown colour indicated the presence of flavonoids.

\section{Triterpenoids}

\section{(a) Liebermann - Burchard's test}

$2 \mathrm{mg}$ of dry extract was dissolved in acetic anhydride, heated to boiling, cooled and then $1 \mathrm{ml}$ of concentrated sulphuric acid was added along the sides of the test tube. Formation of a violet coloured ring indicated the presence of triterpenoids.

\section{Proteins}

\section{(a) Biuret's test}

To $1 \mathrm{ml}$ of hot aqueous extract, 5-8 drops of $10 \% \mathrm{w} / \mathrm{v}$ sodium hydroxide solution, followed by 1 or 2 drops of $3 \% \mathrm{w} / \mathrm{v}$ copper sulphate solution were added. Formation of violet red colour indicated the presence of proteins.

\section{(b) Millon's test}

$1 \mathrm{ml}$ of aqueous extract was dissolved in $1 \mathrm{ml}$ of distilled water and 5-6 drops of Millon's reagent were added. Formation of white precipitate, which turns red on heating, indicated the presence of proteins. 
Vikas R. Mathad et al., Journal of Biomedical and Pharmaceutical Research

\section{Resins}

$1 \mathrm{ml}$ of ethanolic extract was dissolved in acetone and the solution was poured in distilled water. Turbidity indicated the presence of resins.

\section{Saponins}

In a test tube containing about $5 \mathrm{ml}$ of an ethanolic extract, a drop of sodium bicarbonate solution was added. The test tube was shaken vigorously and left for 3 minutes. Formation of honeycomb like froth indicated the presence of saponins.

\section{Steroids}

\section{(a) Libermann -Burchard's test}

$2 \mathrm{mg}$ of dry extract was dissolved in acetic anhydride, heated to boiling, cooled and then $1 \mathrm{ml}$ of concentrated sulphuric acid was added along the sides of the test tube. Formation of green colour indicated the presence of steroids.

\section{(b) Salkowski reaction}

$2 \mathrm{mg}$ of dry extract was shaken with chloroform, to the chloroform layer; sulphuric acid was added slowly by the sides of test tube. Formation of red colour indicated the presence of steroids.

\section{Tannins}

To $1-2 \mathrm{ml}$ of the ethanolic extract, few drops of $5 \% \mathrm{w} / \mathrm{v} \mathrm{FeCl}_{3}$ solution was added. A green colour indicated the presence of gallotannins, while brown colour indicated the presence of pseudotannins.

\section{Starch}

$0.01 \mathrm{~g}$ of lodine and $0.075 \mathrm{~g}$ of potassium iodide were dissolved in $5 \mathrm{ml}$ of distilled water and 2-3 ml of ethanolic extract was added. Formation of blue colour indicated the presence of starch.

\section{In-vitro antioxidant activity:}

The following in-vitro models were carried out to evaluate antioxidant activity.

Reducing power.

1,1-Diphenyl 2 picryl Hydrazyl (DPPH) radical scavenging activity.

\section{Reducing power:}

This method is based on the principle of increase in the absorbance of the reaction mixture. Increase in the absorbance indicates increase in the antioxidant activity. In this method antioxidant compound forms a coloured complex with potassium ferricyanide, trichloro acetic acid and ferric chloride, which is measured at $700 \mathrm{~nm}$. Increase in absorbance of the reaction mixture indicates the reducing power of the Samples. The reducing power of ethanolic extract of stem bark of E. tuberculatus Roxb ${ }^{9}$.

\section{Procedure:}

Different doses of ethanolic extract of stem bark of E. tuberculatus Roxb. were mixed in $1 \mathrm{ml}$ of distilled water so as to get $30 \mu \mathrm{g}, 60 \mu \mathrm{g}, 90 \mu \mathrm{g}$, $120 \mu \mathrm{g}$ and $150 \mu \mathrm{g}$, concentration. This was mixed with phosphate buffer $(2.5 \mathrm{ml}, 0.2 \mathrm{M}, \mathrm{pH} 6.6)$ and potassium ferricyanide $(2.5 \mathrm{ml}, 1 \%)$. The mixture was incubated at $50^{\circ} \mathrm{C}$ for 20 minutes. A portion $(2.5 \mathrm{ml})$ of trichloroacetic acid $(10 \%)$ was added to the mixture, which was then centrifuged at 3000 rpm for 10 minutes if precipitate occurs. The upper layer of the solution $(2.5 \mathrm{ml})$ was mixed with distilled water $(2.5 \mathrm{ml})$ and $\mathrm{FeCl}_{3}(0.5 \mathrm{ml}, 0.1 \%)$, and the absorbance (OD) was measured at $700 \mathrm{~nm}$.

Increased absorbance of the reaction mixture indicates increase in reducing power. The \% reducing power was calculated by using following formula.

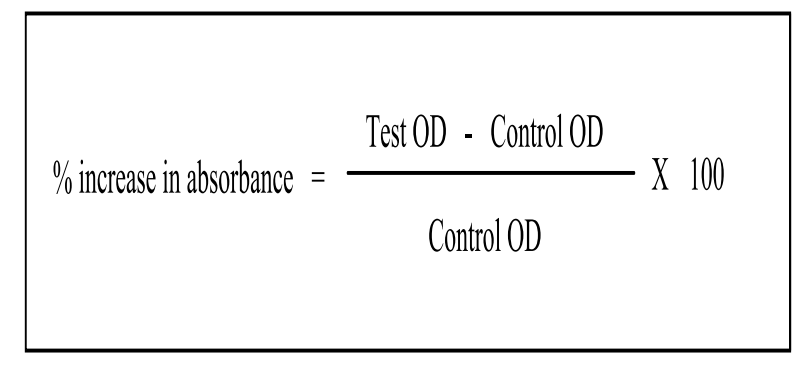

The results are compiled in Table $\mathbf{0 2}$ and graphically shown in Fig. 01.

\section{DPPH radical scavenging activity:}

\section{A) Reagents:}

DPPH: Stock solution of DPPH was prepared by dissolving $13 \mathrm{mg}$ in $10 \mathrm{ml}$ of methanol and then the total volume was made up to $25 \mathrm{ml}$ with methanol in volumetric flask.

Test solutions: The stock solutions of extract were prepared by dissolving $100 \mathrm{mg}$ of dried extracts and constituents in $100 \mathrm{ml}$ of methanol to make a stock solution of $1 \mathrm{mg} / \mathrm{ml}$. Aliquots from this stock solution were further diluted with methanol to get 
the final concentrations viz. $10,20,40,60,80$, and $100 \mu \mathrm{g} / \mathrm{ml}$.

Preparation of ascorbic acid stock solution: Ascorbic acid used as a standard for the study. Ascorbic acid stock solution was prepared in the concentration of $1000 \mathrm{mg} / \mathrm{ml}$ in water. It was prepared freshly and used immediately for the study to avoid the spontaneous decomposition of ascorbic acid in water solution. From the stock solution different concentrations viz. 10, 20, 40,60, 80 , and $100 \mu \mathrm{g} / \mathrm{ml}$ were prepared in water and used for antioxidant studies.

\section{B) DPPH free radical scavenging activity ${ }^{10-12}$}

Free scavenging activity was measured by a decrease in absorbance at $516 \mathrm{~nm}$ of a methanol solution of coloured DPPH brought about by the sample. A stock solution of DPPH $(1.3 \mathrm{mg} / \mathrm{ml}$ in methanol) was prepared such that $75 \mu$ of it in 3 $\mathrm{ml}$ methanol gave an initial absorbance of 0.9. Decrease in the absorbance in the presence of ethanolic extract at different concentrations was noted after $15 \mathrm{~min}$. $\mathrm{EC}_{50}$ (i.e. the concentration of the test solution required to give a $50 \%$ decrease in the absorbance compared to that of blank solution) was calculated from percent inhibition. A blank reading was obtained using methanol instead of the extract. Ascorbic acid was used as standard. The percentage inhibition of antiradical activity was calculated using the formula. The results are compiled in the Table $\mathbf{0 3}$ and graphically shown in Fig. 02.

$$
\% \text { inhibition }=\frac{\text { Absorbance of blank }- \text { Absorbance of test sample }}{\text { Absorbance of blank }} \times 100
$$

The results are compiled in table $\mathbf{0 3}$ and graphically shown in fig.02.

\section{RESULTS AND DISCUSSION}

\section{Phytochemical investigation of the stem bark of Elaeocarpus tuberculatus Roxb.}

Qualitative phytochemical investigation:

Preliminary qualitative phytochemical screening was carried out for the ethanolic extract of
Elaeocarpus tuberculatus Roxb. The presence or absence of active constituents in extract was mentioned in Table 01.

\section{Table 1: Results of qualitative tests for phytoconstituents.}

\begin{tabular}{|l|l|l|}
\hline SI. No. & Test & Inference \\
\hline 1 & $\begin{array}{l}\text { Alkaloids } \\
\text { (a) Dragendroff's test } \\
\text { (b) Hager's test } \\
\text { (c) Wagner's test } \\
\text { (d) Mayer's test }\end{array}$ & - ve \\
& $\begin{array}{l}\text { Carbohydrates } \\
\text { (a) Anthrone test } \\
\text { (b) Benedict's test } \\
\text { (c) Fehling's test } \\
\text { (d) Molisch's test }\end{array}$ & - ve \\
\hline 3 & $\begin{array}{l}\text { Flavanoids } \\
\text { (b) Shinoda's test }\end{array}$ & - -ve \\
& $\begin{array}{l}\text { Triterpenoids } \\
\text { (a) Libermann-Burchard's test }\end{array}$ & -ve \\
\hline 4 & $\begin{array}{l}\text { Proteins } \\
\text { (a) Biurat's test } \\
\text { (b) Millon's test }\end{array}$ & + ve \\
\hline 5 & Saponins & - ve \\
\hline 6 & $\begin{array}{l}\text { Steroids } \\
\text { (a) Libermann-Burchard's test } \\
\text { (b) Salkowaski reaction }\end{array}$ & + ve \\
\hline 7 & Starch & - ve \\
\hline 9 & Tannins & + ve \\
\hline 10 & Resins & - ve \\
\hline
\end{tabular}

The preliminary phytochemical studies revealed the presence of flavonoids, triterpenoids, steroids and tannins from the ethanolic extract of stem bark of Elaeocarpus tuberculatus Roxb.

II. In-vitro anti-oxidant activity of ethanolic extract of stem bark of plant Elaeocarpus tuberculatus Roxb.:

\section{A. Reducing power activity of ethanolic extract of stem bark of $D$. oojeinense :}

It is observed that ethanolic extract have demonstrated concentration dependent increase in the reducing property. Ascorbic acid (std. 100 $\mu \mathrm{g})$ has $546.20 \%$ reducing property. The test extract showed concentration dependent increase in reducing power property. However, $100 \mu \mathrm{g}$ of 
Vikas R. Mathad et al., Journal of Biomedical and Pharmaceutical Research

ethanolic extract showed comparable reducing power i.e. $408.96 \%$. The results are compiled in the Table 02 and graphically shown in Fig. 01.

Table 02: Reducing Power Activity of ethanolic extract of stem bark of plant

\section{E. tuberculatus.}

\begin{tabular}{|l|l|l|}
\hline Group & $\begin{array}{l}\text { Absorbance } \\
\text { Mean } \pm \text { SEM }\end{array}$ & $\begin{array}{l}\% \\
\text { Increase }\end{array}$ \\
\hline Control & $0.145 \pm 0.006$ & -- \\
\hline $\begin{array}{l}\text { Control + standard } 100 \\
\mu \mathrm{g} \text { (Ascorbic acid) }\end{array}$ & $0.937 \pm 0.008^{* * *}$ & 546.20 \\
\hline $\begin{array}{l}\text { Control + Ethanolic } \\
\text { Extract } 20 \mu \mathrm{g}\end{array}$ & $0.286 \pm 0.008^{\mathrm{ns}}$ & 97.20 \\
\hline $\begin{array}{l}\text { Control + Ethanolic } \\
\text { Extract } 40 \mu \mathrm{g}\end{array}$ & $0.420 \pm 0.006^{* * *}$ & 189.65 \\
\hline $\begin{array}{l}\text { Control + Ethanolic } \\
\text { Extract } 60 \mu \mathrm{g}\end{array}$ & $0.571 \pm 0.010^{* * *}$ & 293.79 \\
\hline $\begin{array}{l}\text { Control + Ethanolic } \\
\text { Extract } 80 \mu \mathrm{g}\end{array}$ & $0.698 \pm 0.007^{* * *}$ & 381.37 \\
\hline $\begin{array}{l}\text { Control + Ethanolic } \\
\text { Extract } 100 \mu \mathrm{g}\end{array}$ & $0.738 \pm 0.013^{* * *}$ & 408.96 \\
\hline
\end{tabular}

Values are the mean \pm S.E.M., $n=3$

Significance $* * * P<0.001$, compared to control.

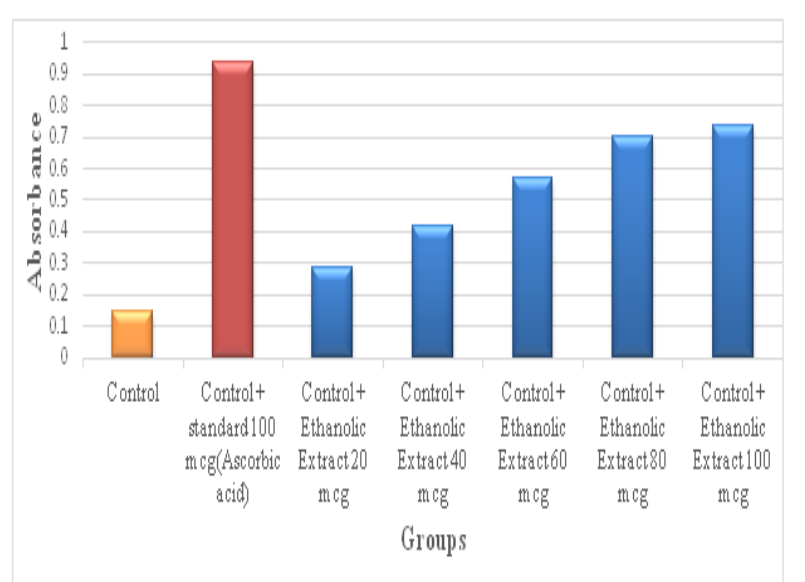

Figure 1: Reducing power activity of ethanolic extract of stem bark of plant

\section{E. tuberculatus.}

B. 1, 1-Diphenyl - 2 -picryl hydrazyl (DPPH) radical scavenging activity:

The free radical scavenging activity of ethanolic extract of stem bark of $E$. tuberculatus is expressed in terms of percentage inhibition. The decrease in percentage of inhibition shows increased absorbance. The decrease in optical absorbance at $517 \mathrm{~nm}$ after addition of the test compounds is measured. The percentage of DPPH radical scavenged for ethanolic extract maximum of $82.88 \%$. The ethanolic extract exhibited a significant concentration dependent inhibition of DPPH activity, with a $50 \%$ inhibition $\left(\mathrm{IC}_{50}\right)$ at a concentration of $50 \mu \mathrm{g}$. The results of extract are given in the Table 03. The $\mathrm{IC}_{50}$ value of ethanolic extract was found to be nearer to the $\mathrm{IC}_{50}$ value of standard Ascorbic acid. The results are compiled in the Table 03 and graphically shown in Fig. 02.

Table 03: DPPH free radical scavenging activity of ethanolic extract of stem bark of plant $E$. tuberculatus.

\begin{tabular}{|l|l|l|}
\hline $\begin{array}{l}\text { Conc. of extract } \\
\text { /std }(\mu \mathrm{g} / \mathrm{ml})\end{array}$ & $\begin{array}{l}\text { Ascorbic acid } \\
\text { \% inhibition }\end{array}$ & $\begin{array}{l}\text { Ethanolic extract } \\
\text { \% inhibition }\end{array}$ \\
\hline $20 \mu \mathrm{g} / \mathrm{ml}$ & $41.38 \pm 1.27$ & $33.09 \pm 1.11$ \\
\hline $40 \mu \mathrm{g} / \mathrm{ml}$ & $62.10 \pm 1.77$ & $45.93 \pm 1.09$ \\
\hline $60 \mu \mathrm{g} / \mathrm{ml}$ & $79.83 \pm 1.68$ & $62.81 \pm 2.05$ \\
\hline $80 \mu \mathrm{g} / \mathrm{ml}$ & $91.21 \pm 2.32$ & $73.86 \pm 2.77$ \\
\hline $100 \mu \mathrm{g} / \mathrm{ml}$ & $92.68 \pm 2.88$ & $82.88 \pm 1.94$ \\
\hline
\end{tabular}

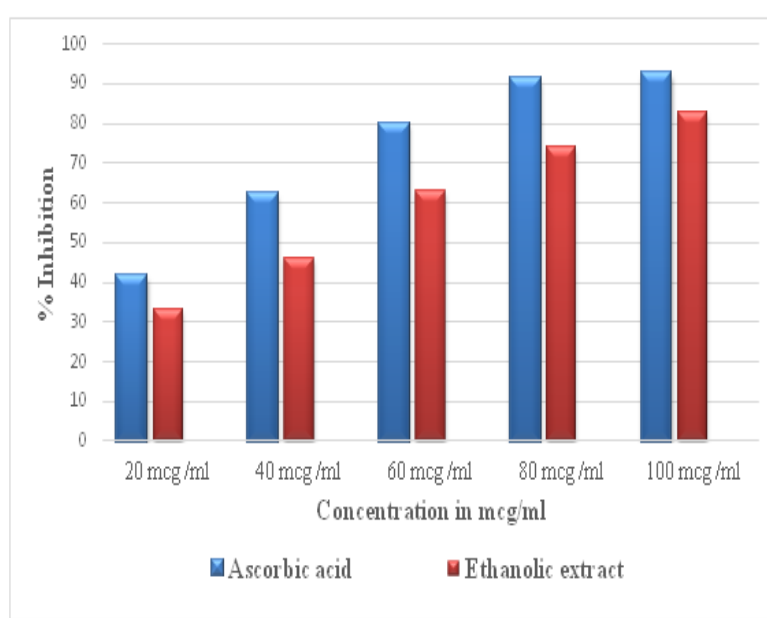

Figure 2: DPPH free radical scavenging activity of ethanolic extract of stem bark of plant $E$. tuberculatus.

\section{CONCLUSION}

The ethanolic extract of stem bark of Elaeocarpus tuberculatus Roxb. was subjected to in-vitro antioxidant activity. The present research work concludes that the ethanolic extract possesses significant concentration dependent inhibition of DPPH activity and concentration dependent increase in reducing power property. 
Vikas R. Mathad et al., Journal of Biomedical and Pharmaceutical Research

The phytoconstituents like flavonoids, triterpenoids, steroids and tannins which are present in this plant may be responsible for the invitro anti-oxidant activity. Thereby justifying their use in the traditional system of medicine.

\section{ACKNOWLEDGEMENT}

The authors are thankful to Dr. Shivamurthy Murugha Sharanaru, President, SJM college of Pharmacy, Chitradurga for providing all necessary facilities through the Principal.

\section{REFERENCES}

1. Valko $M$, Rhodes CJ, Moncol J, Izakovic M, Mazur $M$. Free radicals, metals and antioxidants in oxidative stress-induced cancer. Chem Biol Interact. 2006;160:1-40.

2. Goldfarb AH. Nutritional antioxidants as therapeutic and preventive modalities in exercise-induced muscle damage. Can J Appl Physiol. 1999;24(3):249-266.

3. Pacher $P$, Beckman JS, Liaudet L. Nitric oxide and peroxynitrite in health and disease. Physiol Rev. 2007;87:315-424.

4. Khalaf NA, Ashok KS, Atif Al-Othman, Zaha ElAgbar, Husni Farah. Antioxidant activity of some common plants. Turk J Biol. 2008;32:515.
5. Kritikar KR, Basu BD. Indian Medicinal Plants. Dehradun. International Book Distributors. 1999;1:406.

6. Elaeocarpus tuberculatus Roxb. [Internet]. India Biodiversity Portal. Available from: https://indiabiodiversity.org/species/show/11 335

7. Elaeocarpus tuberculatus Roxb. Elaeocarpaceae [Internet]. Elaeocarpus tuberculatus - Elaeocarpaceae. [cited 2019 Mar 22]. Available from:http://www.Biotic.org /india/species/e/elaetube/elaetubeen.html

8. OECD 425 guidelines. OECD guidelines for testing of chemicals. $2001 \mathrm{Dec} ; 1 / 26: 1-26$.

9. Vani T, Rajani M, Sarkar S, Shishoo CJ. Antioxidant properties of the Ayurvedic formulation Triphala and its constituents. Int J Pharmacog. 1997;35:313-17.

10. Bagul, MS, Ravishankara $M N$, Padh $H$, Rajani M. Phytochemical evaluation and free radical scavenging properties of rhizome of Bergenia ciliata (Haw) Sternb. Forma ligulata Yeo. J Nat Rem. 2003;3:83-9.

11. Rang HP, Dale MM, Ritter JM, Moore PK. Text Book of Pharmacology, Churchill Living stone, $5^{\text {th }}$ ed. Edenburg. 2003;560 -72.

12. Katzung BG. Basic and Clinical Pharmacology, $9^{\text {th }}$ ed. McGraw Hill companies 2004;576 -78. 